\title{
DAVID HEWITT POPE, 1944-2007
}

\author{
By Glenn Withers* \\ Universities Australia; Australian National University
}

\section{BACKGROUND}

Professor David Hewitt Pope was the compleat economic historian. He insisted upon using good theory, displayed sensitive understanding of institutions and was indefatigable in gathering comprehensive empirical evidence to test and explain his propositions. Indeed he went beyond the strictures of his discipline and also linked his economic history to contemporary policy concerns. His death on 17 October 2007 has cost the profession a master practitioner, and his family and friends are now without the ongoing companionship of a delightfully warm human being.

Born in Melbourne in 1944 to John and Nell Pope, David continued to return to Melbourne to regroup and refresh from time to time, and is survived there by his brother John. But David also spent extensive periods in the United States at Ohio State University, Sydney at the University of New South Wales (UNSW), and Canberra at the Australian National University (ANU). He was married to fellow economist Robin Pope for 23 years, 1967-90. Following their separation and divorce he married his second wife Lorelle Thompson-Pope. David and Lorelle moved to Noosa following David's retirement.

His final post before retirement was Professor of Economics in the Institute of Advanced Studies at ANU. He retired early from this post because of invalidity, and despite continuing active commitment to new research projects, in a typically selfless gesture he feared that anything less than complete fitness and capability for his duties meant he was obstructing the way forward for bright young scholars.

A range of visiting appointments at Duke, Austin, Princeton, Wisconsin and Wellington gave him global and comparative perspectives and insights. His work was solidly focussed on Australia, but he was always conscious of the fact that the flows of labour and capital across borders that he so enjoyed examining required both local and overseas explanation. However he did stop short of formal comparative systems analysis himself in his own work - contenting himself with the

* Thanks are due to Amira Allam, Raja Junankar, Cezary Kapucinski and especially Robin Pope and Lorelle Thompson Pope for their assistance. 
inter-temporal comparisons offered by historical change, and with participation in comparative projects where different national specialists contrasted their analyses of common periods or problems. That said, David was well-versed in a wide repertoire of histories. In his teaching, David happily delivered courses in 'Theories and Models in Economic History', 'Research Methods' and 'Econometric History' as well as providing area study courses for Australia and for Europe - such as with his very well-received courses at the University of New South Wales on 'PreIndustrial Europe' and 'European Industrialisation in a Nationalistic Framework'.

David was insistent that country studies were not self-contained. Any area of application, in his view, required the application of a theoretical frame that the experience of the specific area tested. To be informed on theory for the purpose, David drew happily upon the great debates of his early postgraduate years when neoclassical, monetarist and Keynesian notions battled for theoretical ascendancy. David took a basic neoclassical emphasis on accumulation of capital through markets for understanding the very long-run, added Keynesian concern for fluctuations for the short run, and he adopted a monetarist's commitment to the value and importance of data analysis for both. Not being a narrow disciple of any one theoretical approach meant that David also found fascination and stimulus from less formal thinkers such as Schumpeter, Rostow and Kuznets, especially in pondering the longer run. David's pursuit of knowledge nevertheless found its core purpose in the explanation of the economic progress of Australia.

\section{METHODOLOGICAL PREDILEGTIONS AND EVOLUTION}

David was conscious of his own methodological predilections and those of his profession. He adopted many of those he found in his greatly admired Monash University honours and masters thesis supervisor, Gus Sinclair. As befitted his generation, David was, however, even more dedicated than Gus Sinclair to introducing the formal algebraic modelling and quantitative techniques of economics into economic history.

Like Gus Sinclair, David believed in his science having an ethical core with investigating theories and hypotheses possessing potential to improve the world, and hence he believed in the importance of deducing the policy implications of academic findings about the world. In addition, David adopted Gus Sinclair's vision of being an economists' economic historian, one who contributed to economics. This vision was reinforced when, in the early 1970s, David joined Noel Butlin's department at ANU as a PhD student. Noel Butlin had then recently returned from his sabbatical leave at Yale working with Bill Parker, keen to adapt economists' models to explain historical phenomena, while still continuing with his original dedication to the importance of constructing historical time series of economic factors for such explanation.

David saw the economic historian's contributions to economists as coming from an historian's wider perspective on causes. This meant a readiness to include slowly evolving factors such as demography, technology, institutions and culture. 
For some this perspective might lead to economics being seen as a special case of economic history, where demography, culture, technology and institutions are given. But David took a view more of partnership than transcendence, an approach that facilitated many collaborations with economists.

David's keenness for economic historians to contribute to economists' thinking also resulted in his many publications in economics journals. Publishing in economics journals was somewhat unusual at the beginning of his career. A school of British traditionalists preferred linkage of economic history to social and political history, and a more nationalist Australian group preferred a 'stand-alone' approach to the discipline. David was therefore defying several alternate schools and at times felt isolated in this, until more North American influences helped to develop a greater plurality of approaches to the subject in Australia.

David's papers in the late 1960s and early 1970s included dissection of the Milton Friedman-inspired debates on positivism, but with David rather uniquely and quickly transposing the issues to long-run historical explanation.

What test should the court of scientific inference apply to historical explanation, to checking on whether causes had been genuinely identified? David's answer was made clear in an interchange between David (writing with his then wife Robin Pope) and University of New South Wales colleague Kenneth Rivett, in Australian Economic Papers in 1972. There the Popes came down strongly on the side of the 'predictionists', that a hypothesis could be true even if the assumptions leading to that hypothesis were invalid.

Unlike Milton Friedman, however, the Popes saw a role for realistic assumptions embedded together in a theory. In that set of 1972 methodology papers, the Popes argued that corroborated assumptions embedded in a corroborated theory were more likely to generate hypotheses that on investigation would turn out to be empirically confirmed (and thus hypotheses worth investigating), and should have its hypotheses subjected to lower significance levels. In seeking to understand economic phenomena, the Popes' idea was to stress formulation of theories that embed realistic assumptions.

David's primary methodological interest has been in investigating general causes that applied regularly enough over long-enough periods for their impacts to be quantified and for their reliability to be ascertained via tests of statistical inference. Indeed David began his scientific career with the view that the only causes that could be scientifically investigated were those that repeated themselves sufficiently often in sufficiently similar circumstances to be captured in econometric equations. As he put it, scientific inference should be in the form of 'the repetitious testing of the predictions or retrodictions [sic] of generalised historical hypotheses' (1973, p. 2).

David was clear in stating his view that 'story telling' of unique events was deficient as a sufficient source of explanation. He initially relegated such 'story telling' to being a source of hypotheses, facts and critical review, not capable of contributing to the scientific assessment of causes and their effects. His 
methodological views of what constitutes evidence, and what hypotheses can be scientifically investigated, were however to widen.

This widening was most evident for the threshold question of individual persons and historical explanation. The issue arose most starkly for Pope while amassing quantitative data on the demographic impact on Australia of the loss of so many young men in World War I, and on the economic impact that the Treaty of Versailles, with its war reparations, had on capital and people flows to Australia. Keynes' dire assessment, published in 1920, was that the massive reparations imposed on Germany, could destabilise that country and give rise to a dictator.

In reading the correspondence of the negotiations leading to the Versailles treaty, David discovered some 60 years later that it was Australia's prime minister Billy Hughes, who most strongly encouraged French prime minister Georges Clemenceau to demand extreme reparations. At times Clemenceau started to retreat under pressure from other negotiators, who saw extreme demands as dangerous and contrary to the 'norms' of European war settlements. But, Pope discovered, each time Clemenceau temporised, Hughes would interject with exclamations of shame. The outcome was indeed the imposition of extreme reparation demands on Germany. David concluded that were Australia to have had a different prime minister and thus chief negotiator at Versailles, the reparations imposed on Germany might well have been less excessive, thus altering the course of modern history.

David appreciated that his conclusion on the role of Hughes' personality involved a radical extension of his prior conception of scientific causes. Previously he had discounted the role of individuals, and conceived the economy and its history as the outcome of general causes, not personal idiosyncrasies. His scientific methodology had evolved, perhaps becoming, if not eclectic, then at least more complex and refined.

From that point on, especially in his work on banking, David remained alive to the scope for individuals with their unique personalities to alter events. But throughout his career, his primary interest was in investigating general causes that applied regularly enough over long-enough periods for their impacts to be quantified. To this end, he worked assiduously to keep on improving his own quantitative skills alongside the complementary path of teaming up with such quantitative economists and economic historians as Robin Pope, Glenn Withers, Bruce Chapman, Raja Junankar, Cezary Kapuscinski and Bill Mudd. In all these collaborations a common element was formulating theories or hypotheses about generalised causes for testing their assumptions and predictions using the advanced econometric methods of the times.

\section{LONG CYCLES}

Concern over predictability led directly to one area for which David was particularly well-known among international scholars, namely business cycles, and 
especially the notion of 'Long Waves' or 'Kondratieff Cycles'. Threshold questions as to whether and how cycles could be meaningfully identified statistically were engaged, as were the then-related questions of the status of theoretical explanation of such regular economic movements. David published his cycle ideas in the Fournal of Economic History in 1984 and in the Economic Record in 1991, and soon became a major international authority in this field. Among other things, it led to David becoming a friend and ongoing correspondent of Walt Rostow, who had also been an adviser to US president Lyndon Johnson, and robust exchanges took place on the Vietnam War.

On long waves David was nihilistic. Schumpeter had proposed the existence of 'Kondratieff Cycles' based upon innovation waves and experiencing periodicity of 40-60 years. Later authors such as Rostow and Ernest Mandel kept revisiting the apparent empirical regularities underlying the concept and sought to provide coherent causal explanations for this phenomenon, though more related to 'overshooting' and 'undershooting' than to innovation.

Being, as ever, concerned for good theory and good evidence, David reviewed the theories provided and found them logically deficient, and he also found it hard to truly discern the cycles within the empirical data available. Using the then-new techniques of spectral analysis, the very existence of Long Waves in either economic activity measures or in share prices was hard to find, as was any consistency with the proffered causal explanations. It was not surprising therefore that there were as many datings for these cycles as there were theories.

David concluded that '[T]his evidence offers little support to the proponents of Kondratieffs' (1991, p. 158). There was one regularity however: 'Peaks in long wave research would appear to coincide with long wave depressions' (1991, p. 158). As the US Sub-Prime uncertainties of 2007 have degenerated into substantial recession through 2008 and 2009, it is a pity indeed that David is not around to interrogate the resultant next wave of theorists of the long wave.

\section{INTERNATIONAL LABOUR FLOWS}

The first paper ever published by David Pope was while he was still a tutor at Monash in 1968. It stemmed from his honours and masters thesis focus on the migration area and was titled 'Empire Migration to Australia, Canada and New Zealand: 1910-1929', and appeared in Australian Economic Papers. It examined the economic and demographic causes of these labour flows, and the capital flows that they elicited.

In the early 1970s at the Australian National University, in his doctoral thesis, David further examined in more detail the extent to which the traditional 'pushpull' accounts of migration flows provided a satisfactory and coherent body of theory. He introduced a supply-demand formulation of migratory flows developed by Robin Pope as her econometrics term paper for Richard Porter at Ohio State University. He completed his PhD thesis after taking up a lectureship at the University of New South Wales. 
David's masters and doctoral theses and the associated set of publications presaged a life-long interest in the role of demographic and economic factors shaping Australia via immigration. He enjoyed collaboration with like-minded colleagues in this field over the years, including Glenn Withers, Bruce Chapman, Cezary Kapucinski and Raja Junankar. The collaborators could draw on David's deep knowledge of historical and global migration experience. In return they gave David an engagement he relished with contemporary econometric methods and making history relevant to contemporary policy.

Work with Glenn Withers and Bruce Chapman that was published in the Economic Record in 1985, by CEDA in 1986 and in the Fournal of Economic History in 1996, established that migrants did not rob jobs in most circumstances, but created as many jobs as they filled. This finding was counter-intuitive to many and required much replication in the literature before it became an established finding. In fact numerous studies across countries and periods have since affirmed that early finding, confirming that the demand effects of the population flows tend to broadly balance the supply effects. Similar neutrality results for other shortterm macroeconomic variables were established in David's further work with other collaborators, including in a series of four reports for the Australian Federal government's then Bureau of Immigration Research.

Politicians still tend to focus on the more obvious direct supply effects of migrants and to discount or ignore much of their demand (expenditure) effects, but the work by Pope, with Withers in particular, was explicitly used to influence policy in Australia when then immigration minister Chris Hurford persuaded a Labor Cabinet to increase immigration for the first time during a period of rising unemployment. The emergence of likely recession in Australia in 2009 may be a test of whether lessons have been learned well in migration policy. One suspects that without researchers of the calibre of David Pope producing analysis that can provide some evidence to political decision makers, this will prove difficult.

Pursuing this interest in policy himself, David took time away from the university to work with Glenn Withers at the Economic Planning Advisory Commission, as a scholar-in-residence, and with his former UNSW colleague Peter Shergold at the Office of Multicultural Affairs on ethnic integration concerns in contemporary policy.

David also worked on whether the long-run effects of immigration on per capita income were beneficial. From the time of his Masters thesis, he had identified the international capital flows that migration elicits. Noel Butlin had generated outstanding historical time series of Australia's national accounts - time series for which Yale's Bill Parker deems he would have been awarded a Nobel Prize but for the tyranny of distance. These left David keenly aware of the capital and labour components of Australia's production function. He discerned the need for adequate capital increments to maintain per capita income in the face of a rising population, especially during those eras when the population increments were primarily of a lower skill level than that of the resident population. He noted that 
per capita income falls, other things equal, if capital accumulation fails to keep pace the population growth.

David investigated whether capital inputs had in fact kept pace with the migrant inflows before and after the Second World War period. He found no compensating rise in savings rates within Australia to meet the population inflows - the accompanying capital inflows were less, percentage wise, than the population inflows. He concluded that population policies of importing large numbers of limited skilled immigrants had promoted total growth and Australia's manufacturing sector, but at the cost of capital shallowing, and at the cost of a lower per capita income than would otherwise have been the case.

This conclusion for this period contrasted with later work with Glenn Withers for nineteenth-century migration, where scale economies were available, global capital flowed freely and migration was quite skilled, such that Australia stood out as an exception to wage convergence as a general principle governing Old WorldNew World economic linkages. The more modern era of increased skill content of migration and liberalisation of global capital market access post-financial deregulation and floating of the exchange rate, may again have returned migration long-run economic pay-off to the nineteenth century pattern. David would have relished the opportunity to test this hypothesis, particularly as his work had evolved to examine in depth the role of international capital flows, and he could finally have brought the two together fully and be relevant to modern policy settings at the same time.

\section{INTERNATIONAL CAPITAL FLOWS, MONEY AND BANKS}

David's interest in the financial sector also had roots in his honours thesis, as did so much else. It received a fillip from a visit to Monash University in 1968-69 of Bill Dewald from Ohio State University. Bill was stunned by David's understanding of flows of people and capital, and organised for him to take up a Mershon fellowship at Ohio State University. He and his first wife Robin relocated to Columbus Ohio at Bill's invitation.

At Columbus, David deepened his knowledge of monetary matters via his courses with Bill Dewald, who shared David's focus on understanding causal chains properly, and he also met there fellow Australian Bob Edgar. Bob's friendship and later career at the Reserve Bank and then the ANZ bank, aroused David's interest in banking regulation, just as wife Robin's econometric studies at Ohio under P. A. V. B. Swamy helped encourage his continuous updating of econometric technique.

Also when at Columbus, David was diagnosed with Type 1 diabetes. The shock of this discovery brought about some major re-evaluation of the future and the Popes decided to return to Australia and complete studies at home in familiar surroundings, initially at ANU in Noel Butlin's department and then at the University of New South Wales. While Butlin had been unenthusiastic about 
David's financial history focus, in Sydney David pursued the topic again assiduously and soon produced (with Robin Pope) his first monetary paper in the fournal of Money, Credit and Banking in 1980, as a review article. It examined the interwar fights between the Bank of England and the UK Treasury on the alternative ways of managing the gold standard, and on the usefulness of being on that standard.

David then turned to asking how the gold standard operated in Australia. From his undergraduate days, he been interested in the question of just how did UK and other lenders transfer real buying power to their Australian borrowers. Up to World War II, the borrowed money arrived from overseas in the form of bonds, UK bank deposits and gold bullion. But bonds and money are not real goods and services. How exactly did the UK lenders give up real goods and services that got used by their Australian debtors during the period of the loan? A popular monetarist theory was that money causes inflation, that the transfer of real goods and services is effected by the international capital flows pushing up money stocks in Australia and thereby pushing up the price of exports from Australia bought by the UK lenders such that Australia's terms of trade turned against their UK lenders. The export price rise deprived the lending countries of purchasing power, purchasing power that was transferred to the borrowing country, Australia. David found that this monetarist gold bullion theory did not stand up to close examination. He found instead that the capital flows caused the ratio of non-traded (domestic) goods to rise and that this was the primary vehicle that enabled the transfer of real goods and services to occur from 1870-1930.

Next David turned his interest in finance to an examination of Australia's greatest financial crash, Melbourne's 1888 crash. Drawing on risk theory of a kind being developed by Robin Pope, and on insights into commercial banking coming from discussions with Bob Edgar, David's analysis showed importantly that surviving banks were those that had managed risk best and documented precisely how they did this, especially by being better diversified over regions and industries in Australia. David's findings on diversification provide some insight today as to why the Bank of International Settlements regulations (Basel I and II), which do not pay attention to the importance of diversification, may have done less for stability than they should have.

David's analysis of the 1888 crash also revealed two other things. First, it showed the early existence of naturally oligopolistic features of banking services even in this deregulated free-banking era. He therefore felt that the type of regulations introduced into Australian banking after so many banks failed in 1888 were not responsible for the main features of its post-World War II oligopolistic organisation. Second, the UK head offices of some banks put a tighter rein on loans issuable by their Australian managers and thus could better identify when excessive optimism was enticing unwise lending in the boom years preceding the crash. Such banks survived better than those who allowed their optimism-infected Australian managers a freer rein in deciding on loans.

His concern for economic historians to aid in policy discussions led to his later paper, 'Bank Deregulation Yesterday and Today: Lessons of History'. Here 
David depicted the oligopolistic forces and natural scale economies that had generated a cosy oligopoly under the deregulated free-banking era prior to World War I. He presciently predicted that the deregulated system introduced into Australia in the 1980s would have similar results to the two he had discerned in this earlier era. The banking industry could not support a permanent large influx of new entrants he predicted. Consumers would not find deregulation to their benefit. In this he was found right.

In monetary analysis, with Cezary Kapuskinski, David turned to the role of money supply in economic fluctuations and development. Apart from the mammoth study of Milton Friedman and Anna Schwartz, the topic has actually been little explored. David and Cezary chose to study the topic for Australia from the middle of the nineteenth century up to the First World War, for which purpose they constructed a new data set of monetary aggregates. They surveyed the unsettled controversies in the existing literature on how money impacted on the economy in this pre-World War I era.

David had plans to extend his financial investigations. He was proposing new research based on collaboration on 'Free Banking in the Dominions: The case of Canada, Australia and New Zealand' with Neil Quigley of Victoria University Wellington - with a very clear echo being present of his first published paper on immigration. Similarly Mac Boot of ANU and Ian Harper of University of Melbourne were to join with David on analysis of commercial banking regulation. David's illness meant that these projects, and another with Michael Bordo of Rutgers on long-run monetary history, did not come to fruition.

With each of immigration, capital flows and trade in goods and services, David was fascinated by the free movements across borders in these areas in the nineteenth century, and by the contrast that this provided with the regulatory frameworks that were imposed into the twentieth century. As Ian Harper has commented, David was always intellectually stimulating and someone who sought to challenge current thinking. This was why he was interested in free banking, I suppose. It wasn't that he was a natural libertarian - indeed, I suspect, quite the contrary - but he liked the challenge that the free banking literature posed to the generally benign interpretation of the development of central banking available in the literature, e.g., Giblin's Growth of a Central Bank' (personal communication, 10 August 2008).

\section{VALUES IN ECONOMIC HISTORY}

Ian Harper's speculation on ideology is pertinent. This writer suspects that speculation about Pope's instinct being distant from libertarianism is correct. But it is important to recognise that David was not in any way an ideological warrior in his personal views and, certainly not, in his research and teaching. It was rather a case that David saw that the devil lay in the details - that abstract theories of how everything private is good need to be subjected to scientific checks of whether their 
assumptions make sense in particular situations. His background of a father running a family business may have aided him in discerning that contracting out all operations to the private sector, and leaving it to self-regulate, need not automatically generate economic nirvana.

Thus in his analysis of 'free banking' in Australia in the nineteenth century, David examined the role of banks and bankers assiduously, and did reach interventionist conclusions. He provided an institutional, statistical and case study analysis of Australian finance in reaching this position. This analysis ranged from biographical analysis for leading figures such as Thomas Armstrong of the Mutual Life Company (MLC), through regression analysis of the determinants of the capital inflow patterns for Australia to interrogation of the corporate archives for Banks to determine their pay scales. David interpreted how Australian banks transformed themselves from their British origins to match Australia's economic structure, and how the banks had been at the centre of managing the growth of domestic savings and the massive inflow of British capital to support the pastoral, mining, urban and infrastructure investment needs of the country.

The economic peak for the nineteenth-century Australian colonies came in 1888, a recurrent focus for David's research. David writes of how 'the year of Australia's centenary, 1888, was the annus mirabilis of the era of extravagance. In the streets the Jubilee of Queen Victoria's reign was still being celebrated with exhibitions, pageants and brilliant illuminations. In the economy, Australians and foreign investors joined forces in a furious speculation in land and in finance, mining and other company shares'.

And then it all went badly wrong - and the free banking environment played a major part in this. In particular, arrangements for the mutual defence of banks against runs proved completely brittle in the face of individual bank opportunism. With differential risk profiles, stronger banks actually welcomed the demise of weaker competitors and, when all were engulfed in an economy wide maelstrom, 'reconstruction' through new corporate structures helped to handsomely save those stronger banks, with the losses transferred comprehensively to their previous competitors' customers. Certainly a need for government intervention and regulation including, naturally, a central bank, was David's conclusion. But this was not unqualified, as he well-recognised the problems of collective failure, just as he did market failure. David's analysis of the global and national economic events and policy responses in 2008 would have been insightful. But the rundown in teaching and research of economic history and the associated lack of historical insight in economic events has meant policy formation is less sure-footed than it should be.

The recognition of limits to intervention is seen even more in the critical analysis provided by David of the apparatus of the 'Australian Settlement', as it was later termed by the journalist and writer Paul Kelly. This notion referred to the twentieth-century development of tariff protection and minimum wage regulation that grew out of the community reaction to the Depression of the $1890 \mathrm{~s}$. David's work on protection and manufacturing competitiveness (AEHR 1986) makes it clear that he is no dogmatic dirigiste. He delighted in quantifying the 
protection provided by the tariff to the protection provided by distance, determining that the total protection levels accorded to manufacturing during the period to 1930 averaged 35 per cent on foreign goods. But equally, he was assiduous in seeing if this was at least compensation over time for profit, cost and productivity movements, and the answer was that they offset each other; so protection was not increasing.

Perhaps even more telling was David's earlier review of the role of wage regulation. He is crystal clear on not only the nature of the regulation and its measurement but on his evaluation of the system of such regulation. In the Australian Economic History Review in 1982, while most policy economists in Australia and elsewhere were still critiquing labour regulation on a priori grounds, David revealed he had been deep inside the beast counting and analysing. He developed and estimated a complete model of labour supply, demand, wages and productivity, 1900-30, thus empirically accessing the natural experiment of transition from zero regulation to one of the most comprehensive wage-fixing regimes in the industrial countries. He concluded that while wage regulation was clearly intended to protect the living standards of workers, it did not succeed in this endeavour. Rather, wage regulation came to cast 'not a protecting but a harmful shade' (1982, p.125), and especially the rate of unemployment was higher on account of it. David was anticipating and assisting a change of ideas whose time would come under the Hawke-Keating Government of the later 1980s and of the early to mid-1990s, with the winding back of tariffs and the move to enterprise bargaining.

\section{A LIFE WELL-LIVED}

In the end David was an optimist who took pride in the Australian story. He saw in it the realisation of a potential for humans to carve out a good life for themselves through the accumulation of knowledge and learning. In so doing he earned the admiration of the doyens of the profession. William Parker of Yale University saw David as being 'diligent and careful in accumulating data, which he then puts to use with ingenuity and imagination to tell a story and to draw a moral . . . The topics he selects are significant central questions of Australian economic history with relevance to contemporary economic policy. He handles time series well, while keeping a firm hold on the underlying institutional development'.

Bill Parker went further. He compared David with a fellow eminent Australian economic historian, Graeme Snooks, and concluded that David was 'Isaiah Berlin's Fox to Graeme Snooks' Hedgehog: Graeme knows one big thing, but David knew many things' he wrote, adding that 'David's work on bankers shows that he can work on individuals as well as statistics and his work on banking showed he could develop themes and not just projects' (ANU Archives, letter of recommendation, 3 January 1990).

Australia's pre-eminent economic historian, Noel Butlin, characterised David too as follows: 'He has a wide range of research interests in methodology, 
immigration, cyclical activity, banking and human capital. He has a wellestablished reputation overseas particularly in the area of cycles and migration and, of course, is well-known in Australia in all his fields and research interests' (ANU Archives, 16 January 1990).

With such support David was appointed Professorial Fellow at ANU in March 1990 and Professor in April 1992 at the Australian National University, the latter appointment being regrettably all too soon to be followed by his early retirement. This did mean that David's lifelong battle with diabetes and its side-effects was lost.

David did remember his youth as a particularly happy time - 'pre-insulin' as he called it. With friends such as Peter Johns, Rick Payne and David Hutchings, the innocent Australian life of snorkelling, fishing, beer and chips was fondly remembered. But so were 'post-insulin' times of the early 1970s in Canberra with Glenn Withers, Marion Powall, Mary and Lee Alston, Malcolm Tull, Mary MacKinnon, Wayne Naughton and Bob Gregory. Even when David announced that the unusual meat enjoyed at one of the Pope BBQs was a donation from a friend in the ANU Zoology Department, the strong camaraderie did not flag. In Sydney in the later 1970s and early 1980s, there was sailing on Sydney Harbour with colleagues Stephen Nicholas and Peter Shergold. Back in Canberra from the mid-1980s, David and Robin hosted happy barbecues and dinners with colleagues who had remained there, and David formed new bonds with others visiting or who had joined the ANU, including Kosmos Tsokhas, Bruce Chapman, Bill Mudd, Cezary Capuscinski, and Raja Junanakar. Visitors such as Tim Hatton, Alison Booth, Barbara Spencer and Jim Brander joined in the fun, with home-made pavlova served as a reminder of Australian origins for the expatriates among the visitors.

Following separation from Robin Pope at the beginning of the 1990s, David met his second wife, Lorelle, while hosting one of his famous barbecues, when she was literally the 'girl next door' after David bought a new house in Canberra. Their union gave him a new extended family, on top of being a favourite 'uncle' for offspring of his friends. He was also supported with love, warmth and care through all the debilitating later days of his illness. Of course these are personal matters, but a feature of David's life is the wonderful lesson that the two can be combined for the better. Indeed it is easy to recall David's enthusiasm for a nice glass of Aussie Red, including to the last in retirement in Noosa, and to also remember that in 1971 he published his second journal paper on 'Viticulture and Phylloxera in North-East Victoria, 1880-1910', in this very journal, the Australian Economic History Review. That is the compleat economic historian.

\section{DAVID POPE BIBLIOGRAPHY}

\section{Books, government reports, theses}

1. A Cost-Benefit Study of Redistricting in Ohio, Report to Department of Development, Ohio State 1971, pp. 170 (with Robin Pope). 
2. The Peopling of Australia: United Kingdom Immigration from Federation to the Great Depression, Ph.D. thesis, Australian National University, Canberra, 1976.

3. ASEAN-Australian Immigration and the Demise of White Australia, ASEAN-Australia Economic Relations Project, Australian National University, Autumn 1985, pp. 80 (with Peter Shergold).

4. Australia's Greatest Asset: Human Resources in the Nineteenth and Twentieth Centuries, Federation Press, Sydney 1989, Edited pp. 350 (with Lee Alston)

5. Immigration, Wages and Price Stability, Canberra: Australian Government Publishing Service, 1990, (with P.N. Junankar).

6. Recent Immigrants and Housing, Canberra, Australian Government Publishing Service, 1993 (with P.N. Junankar C. Kapuscinski and W. Mudd).

7. Immigration and Australia's External Account Balances, Canberra: AGPS, 1994, (with P.N. Junankar, C.A. Kapuscinski and W.A. Mudd).

\section{Articles, book chapters, and working papers}

8. Empire Migration to Canada, Australia and New Zealand, 1910-29, Australian Economic Papers, December 1968, pp. 167-88. Also reprinted as Monash University, Economics Department, Reprint Series, 16.

9. Viticulture and Phylloxera in North-East Victoria, 1880-1910, Australian Economic History Review, March 1971, pp. 21-38.

10. An Index of Melbourne Building Activity, 1896-1939, Australian Economic Papers, June 1972, pp. 103-11.

11. Predictionists, Assumptionists and the Relatives of the Assumptionists, Australian Economic Papers, December 1972, pp. 224-28 (with Robin Pope).

12. In Defence of Predictionism, Australian Economic Papers, December 1972, pp. 232-398 (with Robin Pope).

13. Epilogue, Australian Economic Papers, December 1972, pp. 239-40 (with Robin Pope).

14. Economic History and Scientific Inference, Australian Economic History Review, March 1973, pp. $1-15$.

15. Australian Immigration: A Critique of the Push-Pull Model, Australian Economic History Revierw, XVI: 2, September 1976, pp. 144-152.

16. The Contribution of United Kingdom Migrants to Australia's Population, Unemployment and Economic Growth: Federation to the Depression, Australian Economic Papers, vol. 16, issue 29, December 1977, pp. 194-210.

17. Economic History in Australian and New Zealand Universities, Neresletter, Economic History Society, January 1978, pp. 4-21 (with P. Shergold).

18. Domestic Monetary Management in Britain, 1918-1939, Foumal of Money Credit and Banking, November 1980, vol. 12 no. 4, part 1, pp. 678-82 (a review article with Robin Pope).

19. Contours of Australian Immigration, 1901-1930, Australian Economic History Review, XX: 1, March 1981, pp. 29-53.

20. Modelling the Peopling of Australia: 1900-1930, Australian Economic Papers, December 1981, pp. 258-82.

21. Assisted Immigration and Federal-State Relations, Australian Fournal of Politics and History, Vol. 28, No. 1, 1982, pp. 21-31.

22. Price Expectations and the Australian Price Level, 1901-1930, Economic Record, December 1982, pp. 328-38.

23. Wage Regulation and Unemployment in Australia, 1900-30, Australian Economic History Reviere, September 1982, pp. 103-27.

24. Immigration and Government Policy: Role and Effect, in Daryl Douglas (ed.), The Economics of Australian Immigration, Sydney, 1982, pp. 165-73.

25. Commonwealth Government Outlays on Immigration, Australian Historical Statistics Bulletin, No. 7, 1983, pp. 7 1-96.

26. Predictionism, in William L. Marr and Baldev Raj, How Economists Explain, UPA Publishers, New York, 1983, pp. 89-100 (with Robin Pope).

27. Factors Inhibiting Immigration in the 1920's, Australian Economic History Review, March 1984, pp. 34-52.

28. Rostow's Kondratieff Cycle in Australia: 1870-1980, fournal of Economic History, Vol. XLIV, No. 3, September 1984, pp. 729-754. 
29. Employment Prospects and the Labour Market in R. Birrell, D. Hill and J. Neville (eds.), Australia's Population: The Coming Crisis, Fontana, 1984, pp. 200-25.

30. State Government Outlays on Immigration, Australian Historical Statistics Bulletin, Vol. 31, No. 2 , 1985, pp. 218-29.

31. Australian Development Strategy: Semantics and Politics, Australian fournal of Politics and History, Vol. 31, No. 2, 1985, pp. 218-29.

32. Immigration and the Labour Market, in Neville R. Nornlan and Kathryn Meikle, The Economic Effects of Immigration on Australia, Vol. 2, CEDA, Department of Immigration, April 1985, pp. 164-291 (with Glenn Withers and Bruce Chapman).

33. Does History Repeat Itself? Economic Monograph, Economic Society of Australia, New South Wales Branch, April 1985.

34. The Trans-Tasman Connection: Facts and Implications of Australia-New Zealand Migration, Fournal of the Australian Population Association, vol. 2, no. 1, May 1985, pp. 55-67.

35. Immigration and Unemployment, Economic Record, June 1985, Vol 61, No. 2, pp. $554-564$ (with Glenn Withers).

36. Immigration and unemployment : a long run perspective, Working papers in economic history (Australian National University), No. 61, December 1985, pp. 29 (with Glenn Withers).

37. Australian Capital Inflow, Sectoral Prices and the Terms of Trade, 1870-1939, Australian Economic Papers, vol. 46, June 1986, pp. 67-82. Also appeared in First Spring Workshop in Australian Economic History, Economic History Department, Australian National University, 1983.

38. Protection and Australian Manufacturers' International Competitiveness: 1901-1939, Australian Economic History Review, Vol. XXXI, No. 1, March, 1986, pp. 21-39.

39. Private Finance, Australians: Historical Statistics, Fairfax, Syme and Weldon, 1987, pp. 238-53.

40. Population and Australian Economic Development: 1900-1930, in Ian McLean and R.R. Maddock (eds), The Australian Economy in the Long Run, Cambridge University Press, 1987, pp. 33-60.

41. Immigration to Australia. A Case Study. National Clearing House for Case Studies in Public Policy, Australian National University, July 1987, pp. 23.

42. The Economics of Immigration: An Analysis of the Economic Consequences of Immigration with Special Reference to Australia, Bicentennial Encyclopedia of the Australian People, Angus and Robertson, 1988, pp. 872-78.

43. Pratten, Herbert Edward, 1865-1928: Minister of Trade and Customs, Australian Dictionary of Biography, vol. 11, Melbourne University Press, Melbourne, 1988.

44. The Relevance of Human Capital in Australia's Greatest Asset: Human Resources in the Nineteenth and Twentieth Centuries, Federation Press, Sydney, 1989, pp. 1-37.

45. Bankers and Banking Business, 1860-1914, in Lee Alston and David Pope (eds) Australia's Greatest Asset: Human Resources in the Nineteenth and Twentieth Centuries, Federation Press, Sydney, 1989, pp. 302-20. Appeared earlier as Australian National University Working Paper Series, No. 85, 1987.

46. Long Waves and the Crash of '87, Economic Record, vol. 67, no. 2, 1991, pp. 158-67.

47. 'Do Migrants RobJobs From Locals? Lessons of Australian History', foumal of Economic History, Vol. 53, No. 4, 1993, pp. 719-42 (with Glenn Withers).

48. Thomas Armstrong: Collier Company Executive, MLC and Civil Leader, Australian Dictionary of Biography, Volume 13, Melbourne University Press, Melbourne, 1993.

49. Bank Deregulation Yesterday and Today: Lessons of History, in Graeme Donald Snooks ed, Historical Analysis in Economics, Routledge, 1993, chapter 10, 171-200. By Graeme Donald Snooks. Also earlier appeared in Australian National University Working Papers in Economic History No. 156. 1991.

50. Free Banking in Australia Before World War I, in Kevin Dowd (ed.), The Experience of Free Banking, London, Routledge, 1996. Also earlier appeared in Australian National University, Working Papers in Economic History, No. 129, 1989.

51. Who needs money and does it matter? A long-run analysis of the effects of money supply on the Australian economy, Paper presented at the 21st Conference of Economists, University of Melbourne, July 1992 (with C.A. Kapuscinski)

52. Do Migrants Cause Current Account Deficits? (Discussion Paper No. 328), Centre for Economic Policy Research, Australian National University, Canberra, June 1995, (with Junankar, P.N., G.A. Kapuscinski and W. A. Mudd). 
53. Balance of Payments Adjustment under the Gold Standard Policies: Canada and Australia Compared, in Bayoumi, T., B. Eichengreen and M.P. Taylor (eds), Modern Perspectives on the Gold Standard, Cambridge University Press, Cambridge, 1996, chapter 8, (with T.J. Dick and J.E. Floyd).

54. Immigration and the Australian Macroeconomy: Perspective and Prospective, Australian Economic Review, 1998, December, vol. 31 (4), 435-444 (with Junankar, P.N and Glenn Withers (1998).

55. Australia's Payments Adjustment and Capital Flows Under the International Gold Standard, 1870-1913, in Bordo, M.D. and F. Capie (eds), Monetary Regimes in Transition, Cambridge University Press, Cambridge, 1999, chapter 7. Also earlier appeared in Working Papers in Economic History, No 141, Australian National University, 1990. 